\title{
La eucaristía, anamnesis del Misterio Pascual de Cristo a la luz de la teología del Concilio Vaticano II Un abordaje a partir de América Latina
}

\author{
Orientador: Luiz Fernando Ribeiro Santana \\ Doutorando: Felipe Ortiz Dominguez \\ Área de Concentração: Teologia Sistemático-Pastoral \\ Linha de Pesquisa: Fé e Cultura \\ Projeto de Pesquisa: Questões atuais de Teologia Litúrgica
}

\begin{abstract}
La celebración eucarística es la fuente y cumbre de la vida cristiana. Es el sacramento por excelencia donde reconocemos a Jesús al partir el pan. Es donde hacemos memoria de la vida de Jesús en favor del reino de los cielos. Es la celebración del Misterio Pascual de Jesús y de la prolepsis de nuestra pascua. Motivados por la reforma litúrgica del Concilio Vaticano II, expresada en la constitución Sacrosanctum Concilium sobre la sagrada liturgia, proponemos un estudio de las fuentes judías de esta práctica para esclarecer los elementos que configuran la fracción del pan, la acción de gracias que torna posible la eucaristía para los cristianos. A la luz de los relatos de la última cena de Jesús en los evangelios sinópticos y la primera carta a los Corintios por parte del apóstol Pablo, nos proponemos enfatizar la importancia de la cena del Señor como sacramento de su presencia en medio de la comunidad. En este sentido, el testimonio de los apóstoles, así como la experiencia de las primeras comunidades cristianas son las referencias para este retorno a las fuentes. Esta tesis propone en este marco, una reflexión crítica acerca del sacramento de la eucaristía, sus orígenes, su configuración como una Nueva Alianza en Jesús y el compromiso que representa su celebración anamnética en nuestros días.
\end{abstract}


En este sentido, la liturgia es el lugar privilegiado del encuentro entre la fe y la vida, entre la celebración y el compromiso. La eucaristía es el sacramento donde se actualiza el Misterio Pascual de Cristo y se manifiesta nuestra salvación. De ahí la importancia de la estrecha relación entre celebración sacramental lex orandi y el compromiso ético-cristiano lex vivendi.

Palavras-chave: Eucaristía. Misterio Pascual. Reino de Dios. 